\title{
Analysis of Traditional Food Additive Kolakhar for its Physico-Chemical Parameters and Antimicrobial Activity
}

\section{Mudiar Rinky Hemanta ${ }^{1^{*}}$, Varsha Kelkar Mane ${ }^{2}$ and Ashok Bhagwat ${ }^{2}$}

${ }^{1}$ Department of Biotechnology, N. B. Mehta Science and Commerce College, Bordi, Maharashtra, India

${ }^{2}$ Department of Biotechnology, University of Mumbai, Santacruz, Maharashtra, India

\section{Abstract}

Kolakhar had been prepared from banana plants and used by people of Assam since time immemorial. This work has investigated its physicochemical properties as well as its activity against pathogenic micro-organisms. This highly alkaline preparation is found to contain high amount of alkali elements and significant quantity of vanadium and zinc along with its inhibitory property against the tested strains. The bioactivity of kolakhar may be attributed to its very high pH due to its metal content. Thus, this traditional food additive has potential therapeutic applications along with providing the trace element like vanadium.
\end{abstract}

Keywords: Kolakhar; Musa balbisiana colla; Atomic absorption spectroscopy; Bioassay

\section{Introduction}

Kolakhar is a traditional ingredient and a popular food additive in Assam. This antacid is made by filtering water through the ashes of a banana tree (the name derived from the local term of Banana, "kol" or "kola"). It can be made from banana stem, rhizome and peel. Amongst the available varieties of banana in North East region, khar made from Musa balbisiana Colla (a wild variety heavily seeded banana tree) has the best quality.

Along with its routine use as food additive in cooking, kolakhar has been used to treat various ailments. It is used to normalize digestive disorders of stomach and to prevent bacterial attacks on freshly cut injury to heal fast. Use of kolakhar as soaps and detergent for washing clothes and shampooing hair has been practiced in villages. It is also used by farmers to kill leaches and prevent their attack while working in leech infected fields. It also cures and prevents certain cattle diseases [1].

M. balbisiana (athiya kol/ bhim kol) is an indigenous variety of banana in Assam. Young banana pseudo-stem is cooked as vegetable (called posola) which is a very rich source of iron and fibers. Rhizomous stem exudates intake of this plant treat dysentery [2], pinworm infection [2] as well as sore throat. Ability of liquid exudates of banana trunk in treating infertility in males has also been reported. Banana plant has been found to possess insecticidal [3], anthelminthic [4], anti-ulcer genic, anti-microbial [5], anti-venom, anti-allergic, anti-hyperlipidemia, antidiabetic [6], anti-oxidant [5-8] as well as anticancer properties. Banana and its pseudo-stem contain pathogenesis proteins possessing antimicrobial properties. However, bioactivity of kolakhar against micro-organisms has not been reported yet [9]. Till date, only chemical investigation of kolakhar has been carried out.

Objective: The current research focuses on the physicochemical parameters of the food additive as well as anti-microbial effect of kolakhar on various pathogenic micro-organisms [10].

\section{Methodology}

\section{Sample preparation}

Kolakhar was prepared by traditional method. Briefly, pseudostem of a mature healthy tree of M. balbisiana was collected (from Kahilipara, Guwahati, Assam), cut into pieces and kept under sun drying for 10 days. After complete drying, the pieces were burned into ashes and sieved. $50 \mathrm{gm}$ of this ash was suspended in $100 \mathrm{ml}$ sterile deionized water and filtered through muslin cloth. This filtrate $(50 \%$ aqueous extract) is referred to as kolakhar and it can be stored at RT for a year.

\section{Physicochemical analysis}

The kolakhar sample was tested for physicochemical characteristics namely pH, Electrical Conductivity (EC), TOTAL SOLIDS (TS), Total alkalinity, Total hardness, $\mathrm{Na}^{+}, \mathrm{K}^{+}$and $\mathrm{Cl}^{-}$content. The reagents used were of AR grade and deionized water was used for reagent preparation.

\section{Elemental analysis}

The sample was analyzed for $\mathrm{Zn}, \mathrm{Pb}, \mathrm{Cd}$, As and $\mathrm{V}$ using inductively coupled plasma Atomic Absorption Spectroscopy (AAS). The analysis was carried out in SAIF (IIT, Bombay).

\section{Bioassay}

The activity of kolakhar on micro-organisms was checked by agar cup method. Nine pathogenic strains of micro-organisms were inoculated in $\mathrm{MH}$ agar (from Hi-Media) and $0.1 \mathrm{ml}$ sample was added to the wells of $10 \mathrm{~mm}$ diameter. The plates were kept for prediffusion under refrigeration. After incubation at $37^{\circ} \mathrm{C}$ for 24 hours, the diameters of zone of inhibition were measured. Sterile distilled water was taken as control for experiment.

\section{Result and Discussions}

The results for physicochemical, elemental and bioassay are presented in Tables 1-3 respectively.

Kolakhar prepared from M. balbisiena was found to have very high $\mathrm{pH}$ ( $\mathrm{pH}$ 13.0). Also, the sample was found to contain significant amount

*Corresonding author: Hemanta MR, Department of Biotechnology, N. B. Mehta Science and Commerce College, Bordi, Maharashtra, India, Tel: 02528254357; Fax: +1-215-233-6406; E-mail: rinky.mudiar@gmail.com

Received July 16, 2014; Accepted October 22, 2014; Published November 04 2014

Citation: Hemanta MR, Mane VK, Bhagwat A (2014) Analysis of Traditional Food Additive Kolakhar for its Physico-Chemical Parameters and Antimicrobial Activity. Food Process Technol 5: 387. doi:10.4172/2157-7110.1000387

Copyright: ( 2014 Hemanta MR, et al. This is an open-access article distributed under the terms of the Creative Commons Attribution License, which permits unrestricted use, distribution, and reproduction in any medium, provided the original author and source are credited. 
Citation: Hemanta MR, Mane VK, Bhagwat A (2014) Analysis of Traditional Food Additive Kolakhar for its Physico-Chemical Parameters and Antimicrobial Activity. J Food Process Technol 5: 387. doi:10.4172/2157-7110.1000387

Page 2 of 2

\begin{tabular}{|c|c|}
\hline Parameters & Results \\
\hline $\mathbf{p H}$ & $\mathrm{pH} 13.0$ \\
\hline $\mathbf{E C}(\mathbf{m S} / \mathbf{c m})$ & 84.5 \\
\hline TS $(\mathbf{p p m})$ & 289700 \\
\hline Total alkalinity $(\mathbf{p p m})$ & 45500 \\
\hline Total hardness $(\mathbf{p p m})$ & 940 \\
\hline Chloride $(\mathbf{p p m})$ & 24850 \\
\hline $\mathbf{N a}^{+}$content $(\mathbf{p p m})$ & 16.5 \\
\hline $\mathbf{K}^{+}$content $(\mathbf{p p m})$ & 1740 \\
\hline
\end{tabular}

Table 1: Physicochemical parameter result of kolakhar

\begin{tabular}{|c|c|}
\hline Elements & Concentration (ppm) \\
\hline $\mathbf{Z n}(\mathbf{p p m})$ & 0.027 \\
\hline $\mathbf{P b}(\mathbf{p p m})$ & $<0.01$ \\
\hline $\mathbf{C d}(\mathbf{p p m})$ & $<0.01$ \\
\hline $\mathbf{V}(\mathbf{p p m})$ & 0.4 \\
\hline As (ppm) & $<0.01$ \\
\hline
\end{tabular}

Table 2: Elemental analysis of kolakhar by AAS

\begin{tabular}{|l|c|c|}
\hline S.no. & Pathogens & Diameter of zone of inhibition (mm) \\
\hline Control & Sterile Distilled water & 10 \\
\hline $\mathbf{1}$ & P. aeruginosa & 26 \\
\hline $\mathbf{2}$ & K. pneumoniae & 23 \\
\hline $\mathbf{3}$ & S. typhi & 22 \\
\hline $\mathbf{4}$ & Proteus vulgaris & 20 \\
\hline $\mathbf{5}$ & C. diphtheriae & 19 \\
\hline $\mathbf{6}$ & E.coli & 19 \\
\hline $\mathbf{7}$ & S. paratyphi A & 18 \\
\hline $\mathbf{8}$ & S. paratyphi B & 17 \\
\hline $\mathbf{9}$ & Shigella & 15 \\
\hline
\end{tabular}

Table 3: Result of bioassay of kolakhar

of vanadium and zinc. Banana plant is accumulating the elements from soil and water and hence contributing to its high amount in the Kolakhar.
This bio-antacid was found to inhibit the growth of the pathogens used. The bioactivity of Kolakhar may be attributed to its high alkalinity which is mainly due to its alkali element such as potassium, sodium, calcium, carbonate, chloride etc. P. aeruginosa was found to be more sensitive towards kolakhar followed by others.

Hence, these results evaluate the use of this traditional food additive among the native people of Assam.

\section{Acknowledgement}

The authors are thankful to the Department of Biotechnology, N. B. Mehta Science and Commerce College, Bordi, Maharashtra, India, and SAIF, IIT Bombay for supporting the research work. Sincere thanks to Mr. \& Mrs. Mudiar for helping in sample collection.

\section{References}

1. Dibakar CD (2007) Chemical and sopectroscopic investigation of kolakhar and its commercial importance. Indian Journal of Traditional knowledge 6: 72-78.

2. Kalita D, Bikash D (2004) Some folk medicines used by Sonowal Kacharis Tribe of the Brahmaputra valley. Natural Product Radiance 3: 240-246.

3. Debabandya M (2010) Banana and it's by product utilization: an overview. Journal of Scientific and Industrial Research 69: 323-329.

4. Hussain A (2010) In vitro screening of the leaves of musa paradisiaca for anthelminthic activity. The Journal of Animal \& Plant Sciences 20: 5-8.

5. Preeti J (2011) Antibacterial and antioxidant activities of local seeded banana fruits. African Journal of Pharmacy and Pharmacology 5: 1398-1403.

6. Kadhirvel K (2010) Investigations on Anti-Diabetic Medicinal Plants Used by Tribal Inhabitants of Nalamankadai, Chitteri Reserve Forest, Dharmapuri. Ethnobotanical Leaflets 14: 236-247.

7. Arawande JO Komolafe EA (2010) Antioxidative Potentials of Banana and Plantain Peel Extracts on Crude Palm Oil. Ethnobotanical Leaflets14: 559-569.

8. Adinarayana KPS, Babu AP (2011) Anti-oxidant activity and cytotoxicity of ethanolic extracts from rhizome of Musa acuminate. Natural Science 3: 291294.

9. Singh AK (2004) Arsenic Contamination in Groundwater of North Eastern India National seminar on Hydrology with focal theme on "Water Quality".

10. John FS, Ronald S (1999) Oremland Bacterial respiration of arsenic and selenium. FEMS Microbiology Reviews 23: 615-627. 